\title{
NEWS FROM THE WESTERN FRONT: OCCURRENCE OF MEDITERRANEA DEPRESSA (STERKI, 1880) (MOLLUSCA: GASTROPODA: OXYCHILIDAE) IN THE VOSGES AND JURA MOUNTAINS (NORTH-EASTERN FRANCE)
}

\author{
JEAN-MICHEL BICHAIN $^{1 *}$, JULIEN RYELANDT ${ }^{2}$
}

\begin{abstract}
${ }^{1}$ Malacologie, Musée d'Histoire naturelle et d'Ethnographie de Colmar, 11 rue Turenne, 68000, Colmar, France (e-mail: jean-michel.bichain@museumcolmar.org); (1) https://orcid.org/0000-0003-3849-9364

${ }^{2}$ Malacologie, CBNFC-ORI, Conservatoire Botanique National de Franche Comté - Observatoire régional des Invertébrés, France; (1) https://orcid.org/0000-0001-6419-8069

*corresponding author
\end{abstract}

\begin{abstract}
We report here the first record of Mediterranea depressa (Sterki, 1880) in the north-eastern quarter of France, in the Vosges and Jura massifs. After the fortuitous discovery of some shells attributed to $M$. depressa in the southern Vosges Mts., an extensive sampling campaign was carried out both in the Vosges and in the Jura Mts. In total, about 20 shells and seven live specimens were found at eight localities, which, according to the present state of our knowledge, represent its north-western range limit. The species was found exclusively under stones of rocky slope screes on siliceous and calcareous substrates. Some of these habitats could be described as Mesovoid Shallow Substratum. It is not clear whether the rarity of the species is an effect of under-sampling or of its small size and unusual habitat or/and to intrinsic rarity due to isolated populations at the distribution limits of the species. The extreme north-eastern quarter of France constitutes an oceanic-continental transition zone where about thirty gastropod species from Central and Eastern Europe are currently documented at the western limit of their ranges.
\end{abstract}

KEY WORDS: Jura; Vosges; slope screes; Mediterranea depressa; biogeographic limit; Mesovoid Shallow Substratum

\section{INTRODUCTION}

The Flat Gloss snail, Mediterranea depressa (Sterki, 1880), is a Carpathian-Alpine species with a wide distribution in Eastern and Central Europe that extends from the eastern border of France to the Romanian Carpathians (Fig. 1). The species reaches the Black Forest in Germany and Poland in the north, and northern Greece at the southern limit of its range. It also occurs in the mountain areas of Albania (FEHÉr \& ERŐss 2009), Austria, Bosnia and Herzegovina, Bulgaria, Croatia, Czech and Slovak Republics (HORSÁK et al. 2013), Germany, Hungary, Italy (CIANFANELLI et al. 2005), Liechtenstein, Montenegro, North Macedonia, Serbia, Slovenia and
Switzerland (RÜETSCHI et al. 2012) (for overview see WELTER-SCHUltes 2012 and NEIBER 2017).

According to WELTER-SCHULTES (2012), this species is mainly found in moderately humid and rocky forests, but also in various other habitat types such as open grassy mountain slopes above the tree line or in habitats with scattered shrubs or trees. It also inhabits rocks rich in crevices and colonises retaining walls of dry stones (RÜETSCHI et al. 2012) or ruins of mediaeval castles (JUŘIČKOVÁ \& KUČERA 2004). It occurs mainly on calcareous substrates but also tolerates siliceous substrates and reaches elevations of up to $2,600 \mathrm{~m}$ in Switzerland and 2,000 $\mathrm{m}$ in Italy. 


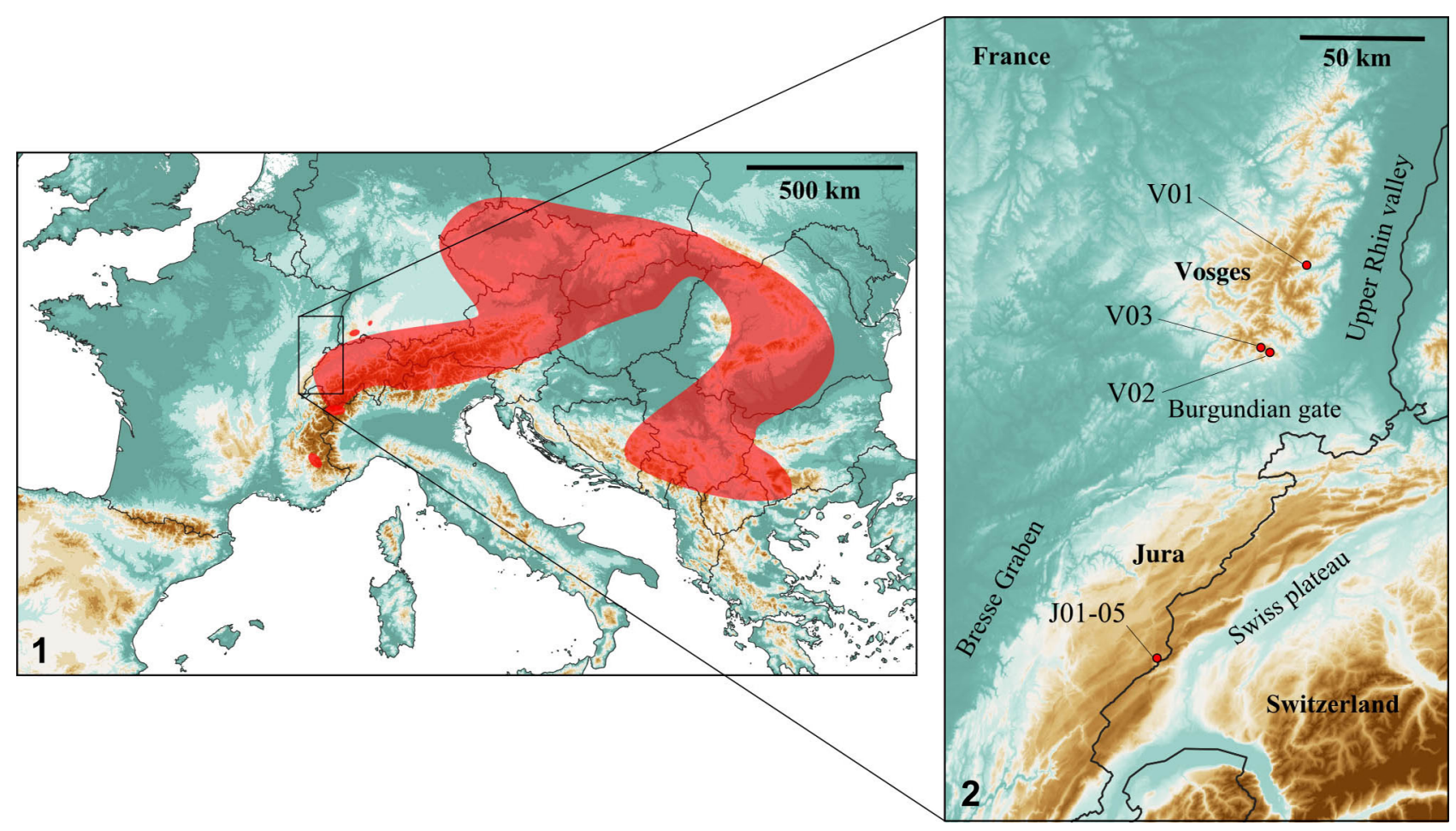

Figs 1-2. Mediterranea depressa (Sterki, 1880): 1 - Geographic distribution of Mediterranea depressa (Sterki, 1880) after WELTER-SCHUlTES (2012) and NEIBER (2017); 2 - sampling sites in north-eastern France (see Material and Methods for details of each locality). Locality V01, Mittlach, Haut-Rhin, alt. 601 m; locality V02, Lamadeleine-Val-des-Anges, Territoire de Belfort, alt. 560 m; locality V03, Riervescemont, Territoire de Belfort, alt. 675 m; localities J01-05, Jougne, Doubs, alt. from $1,155 \mathrm{~m}$ to $1,300 \mathrm{~m}$ a.s.l.

The Flat Gloss snail is also reported from subterranean and edaphic environment, in caves (NEGREA 1975, KoCOT-ZALEWSKA \& DOMAGAEA 2020), within superficial subterranean habitats up to $65 \mathrm{~cm}$ deep (RENDOš et al. 2014) and frequently in mountain scree slope areas (CIANFANELLI et al. 2005). For these reasons, $M$. depressa can be regarded as a species with a tolerance or affinity to subterranean habitats.

The western edge of the Alps in Switzerland, Italy and France currently represents the western limit of the species' distribution. In the Swiss Alps, except the south of Tessin and westernmost Switzerland, the species has been documented from about 130 localities (François ClAUDE 2021, personal communication). CIANFANELLI et al. (2005) recorded it in two isolated localities in the westernmost Italian Alps, one of which is on the border with France.

In France, $M$. depressa was first recorded by FAVRE (1927) from the Haute-Savoie Alps near Cluses.
According to the INPN collaborative database (https://inpn.mnh.fr, accessed July 15th, 2021), the species is still poorly documented in France with only eight records, all located in two adjacent valleys in the Alps of Haute-Provence. However, it remains unclear whether its rarity reflects insufficient field research in hypogean habitats or/and the scattered distribution and low density of its populations at the fringes of its range.

After the fortuitous discovery by one of us (JR) of an empty shell attributable to $M$. depressa in the south of the Vosges Mts. (north-eastern France), an extensive campaign was carried out not only in the Vosges but also in the Jura. The main objectives of this article are (1) to provide diagnostic characters that allow the unambiguous identification of this species and its distinction from other oxychilid species, (2) to provide a description of its habitats, and (3) to present the accompanying gastropod assemblages.

\section{MATERIAL AND METHODS}

\section{STUDY AREA AND SAMPLING METHODS}

The study area includes the southern Vosges and Jura mountain ranges in north-eastern France (Fig. 2) which are located in the two administrative re- gions of Grand Est and Bourgogne-Franche-Comté (BICHAIN et al. 2021). The Vosges are a low mountain range (highest point $1,424 \mathrm{~m}$ ) located near the German border. With the Palatinate Forest on the German side, to the north, they form a single geo- 

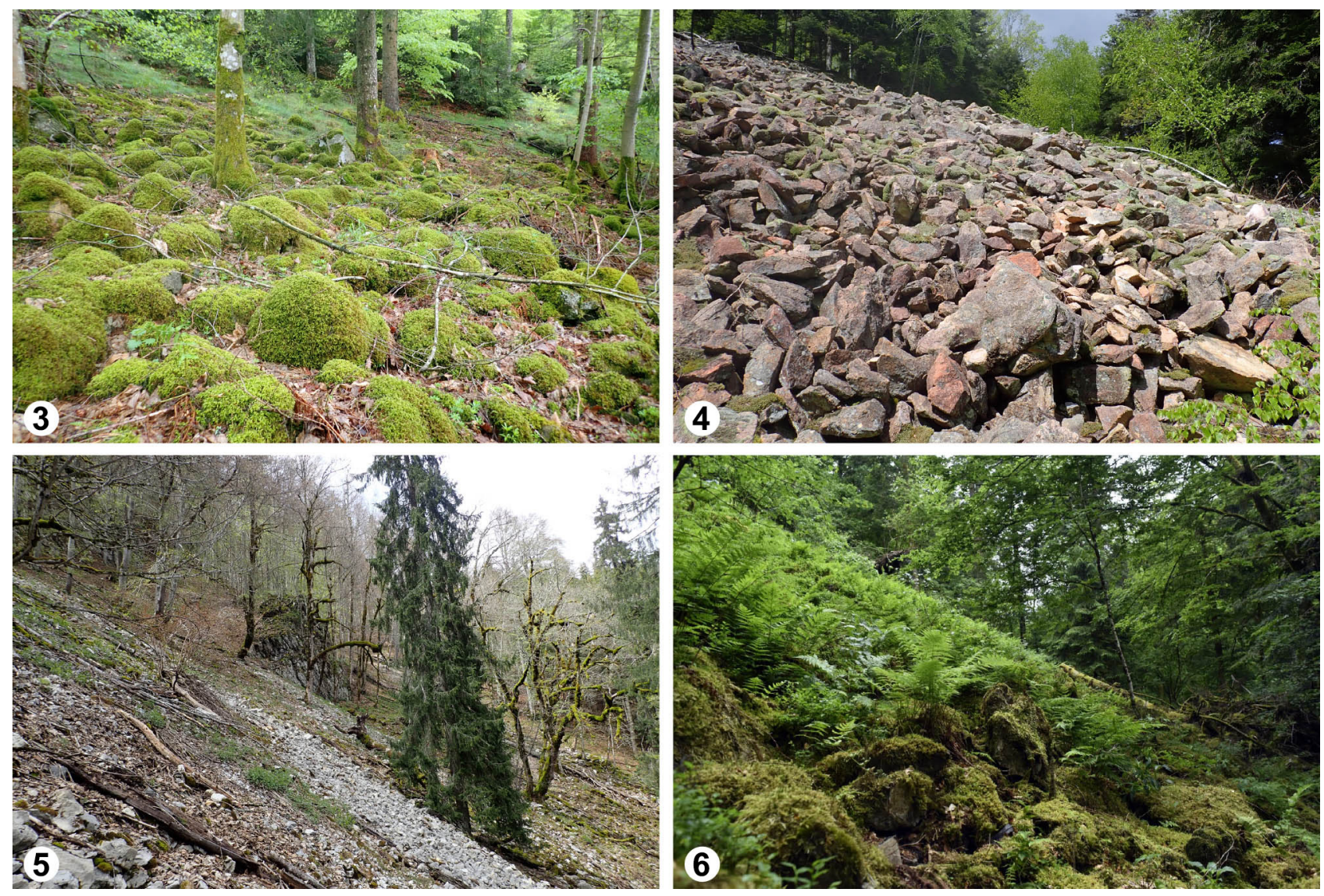

Figs 3-6. Sampling sites of Mediterranea depressa (Sterki, 1880) in the Vosges and Jura mountains: 3 - scattered granitic scree on a gentle slope in a forested landscape, southern Vosges (locality V02, Lamadeleine-Val-des-Anges); 4 - scree dotted with a few fir and birch trees, southern Vosges (locality V03, Riervescemont); 5 - beech-fir forest on limestone scree, Jura (locality J02, Jougne); 6 - granitic scree on a steep slope with a thick and dense moss cover, beech wood, central Vosges (locality V01, Mittlach)

morphological unit of about $8,000 \mathrm{~km}^{2}$. The Vosges form a SW-NE-oriented relief and represent the western border of the Upper Rhine Valley, the Black Forest in Germany forming its eastern boundary. The southern and central parts of the massif, also called the High Vosges, are mainly constituted by granites, gneiss, and volcanic rocks (ELLER et al. 1970b, FLÜCK et al. 1991). The northern of the massif is covered by sandstones (ELLER et al. 1970a). The Vosges are located in a transition zone between oceanic and continental climates, with average annual temperature and precipitation at the highest altitudes of about $4{ }^{\circ} \mathrm{C}$ and $2,000 \mathrm{~mm}$, respectively.

The Jura can be broadly defined as a folded limestone massif marked by a continental mountain climate with a surface area of $14,000 \mathrm{~km}^{2}$ that extends over $340 \mathrm{~km}$ from north to south and delimits a long part of the French-Swiss border with the highest point at $1,720 \mathrm{~m}$. At this altitude, the average annual temperature and precipitation are about $1{ }^{\circ} \mathrm{C}$ and $1,900 \mathrm{~mm}$, respectively. Shaped like a crescent, $70 \mathrm{~km}$ wide at its widest point, it is delimited by the Bresse Graben to the west and the Swiss plateau to the east, the Burgundian gate (also called the Belfort gap) to the north which separates it from the Vosges massif, and it extends southwards to the Bugey plateau. It is characterised by a multitude of folds and plateaus with a rich karstic network and incised with valleys, as well as numerous depressions sheltering peaty complexes.

In these two areas, sampling was carried out mainly in scree slopes, habitats documented as favourable to $M$. depressa (CIANFANELLI et al. 2005, RENDOš et al. 2014). In order to access the interstitial zone, it was often necessary to remove the upper layer of vegetation, soil and litter. Specimens were collected directly by hand. In addition, both live individuals and empty shells of all gastropod species encountered on the surface, or within the excavations, were recorded.

\section{SHELL MEASUREMENTS AND ANATOMY OF THE REPRODUCTIVE SYSTEM}

Empty shells of $M$. depressa were mounted on an adhesive support to aid shell orientation and then imaged with a graduated scale using a stereomicroscope connected to a digital camera. Six parameters were recorded on each picture using the ToupView 
software version 3.7: height (SH) and width (SW) of the shell, aperture height (AH) and width (AW), umbilicus width (UW) and number of whorls (NW) (see HUANG et al. 2014: fig 1, for details of the measurements performed).

Live juveniles and adults were photographed in the laboratory using a Nikon D700 camera equipped with a $150 \mathrm{~mm}$ macro lens. For anatomical studies, animals were drowned in water for about 12 hours and then preserved in a $75 \%$ ethanol solution. Bodies were extracted by breaking the shells with round-tip tweezers. All dissections were performed under a stereomicroscope using thin-pointed forceps. Reproductive systems were dissected out and photographed. Line drawings were done by hand from the photographs. The nomenclature used here to describe the different parts of the reproductive system follows CIANFANELLI et al. (2005).

\section{RESULTS}

\section{Family Oxychilidae Hesse, 1927 (1879)}

Genus Mediterranea Clessin, 1880

\section{Mediterranea depressa (Sterki, 1880)}

Basionym: Hyalina depressa STERKI 1880: 104-105 Previous generic assignments:

Oxychilus depressus: GERMAIN (1931), KERNEY et al. (1999), WeLter-SCHULTES (2012), HORSÁK et al. (2013);

Oxychilus (Morlina) depressus: RIEDEL (1957);

Oxychilus (Riedelius) depressus: HUDEC (1961), RIEDEL (1969), NEGREA (1975);

Mediterranea depressa: FALKNER et al. (2001, 2002), BANK \& NEUBERT (2017);

Riedeliconcha depressa: SCHILEYKO (2003), SYSOEV \& SCHILEYKO (2009).

Systematics: There is no clear consensus on the taxonomic contours of genera within the Oxychilidae (RIEDEL 1980, 1998), in particular for the former subgenera traditionally included in Oxychilus Fitzinger, 1833 (for overview see CIANFANELLI et al. 2005) and ranked as full genera by FALKNER et al. $(2001,2002)$ and currently adopted in MolluscaBase (www.molluscabase.org, accessed July 15th, 2021). A global revision of the Oxychilidae using integrative taxonomic approaches (DAYRAT 2005) combining morpho-anatomical and molecular characters is necessary to evaluate phylogenetic groupings within the family. A family revision is beyond the scope of this paper and we follow CIANFANELLI et al. (2005) in assigning the nominal species Hyalina depressa Sterki, 1880 to the genus Mediterranea Clessin, 1880.
The nomenclature of all the taxa cited in this article follows MolluscaBase (www.molluscabase.org, accessed July 15th, 2021).

\section{ABBREVIATIONS}

Institutions and collections: MHNEC - Musée d'Histoire naturelle et d'Ethnographie, Colmar (France); CBNFC-ORI - Conservatoire Botanique National de Franche-Comté - Observatoire régional des Invertébrés, Besançon (France); JMBC - J.-M. Bichain collection, Colmar (France)

Anatomical description (text and Fig. 16): BC bursa copulatrix; DBC - duct of bursa copulatrix; E epiphallus; FO - free oviduct; P - penis; POS - prostatic portion of spermoviduct; PR - penial retractor; PS - penial sheath; UOS - uterine portion of spermoviduct; V - vagina; VD - vas deferens; VG - vaginal gland.

\section{Material examined:}

France, Vosges: V01 - Mittlach, Haut-Rhin, $48^{\circ} 00^{\prime} 16.35^{\prime \prime} \mathrm{N}, 07^{\circ} 01^{\prime} 00.90^{\prime \prime} \mathrm{E}$, alt. $601 \mathrm{~m}$, collector J.-M. BICHAIN, 03/06/2021, 3 empty shells and 3 live specimens ( 2 adults and 1 juvenile), MHNEC and JMBC; V02 - Lamadeleine-Val-des-Anges, Territoire de Belfort, $47^{\circ} 44^{\prime} 56.5^{\prime \prime} \mathrm{N}, 06^{\circ} 54^{\prime} 54.5^{\prime \prime} \mathrm{E}$, alt. $560 \mathrm{~m}$, collectors J. RYELANDT and J.-M. BICHAIN, 02/06/2020 and 12/05/2021, 4 empty shells, 2 live juveniles, CBNFC-ORI; V03 - Riervescemont, Territoire de Belfort, 47 $45^{\prime} 58.5^{\prime \prime} \mathrm{N}, 06^{\circ} 51^{\prime} 53.6^{\prime \prime} \mathrm{E}$, alt. $675 \mathrm{~m}$, collectors J. RYELANDT and J.-M. BICHAIN, 2 empty shells, 2 live juveniles, collection CBNFC-ORI; Jura:J01 - Jougne, Doubs, 46²3'28.0"N, 06²1'56.8"E, alt. 1,155 m, collector J. RYELANDT, 18/05/2021, 3 empty shells; J02 - Jougne, Doubs, $46^{\circ} 43^{\prime} 40.8^{\prime \prime} \mathrm{N}$, $06^{\circ} 21^{\prime} 35.5^{\prime \prime} \mathrm{E}$, alt. $1,300 \mathrm{~m}$, collector J. RYELANDT, 18/05/2021, 2 empty shells; J03 - Jougne, Doubs, $46^{\circ} 43^{\prime} 27.7^{\prime \prime} \mathrm{N}, 06^{\circ} 21^{\prime} 40.3^{\prime \prime} \mathrm{E}$, alt. 1,235 m, collector J. RYELANDT, 18/05/2021, 1 empty shell; J04 - Jougne, Doubs, $46^{\circ} 44^{\prime} 19.5^{\prime \prime} \mathrm{N}, 06^{\circ} 21^{\prime} 28.0^{\prime \prime} \mathrm{E}$, alt. $1,160 \mathrm{~m}$, collector J. RYELANDT, 14/05/2021, 1 empty shell; J05 - Jougne, Doubs, 4644'16.3"N, 06²1'24.1"E, alt. 1,200 m, collector J. RYELANDT, 14/05/2021, 5 empty shells.

Habitats: In the Jura Mts (Fig. 2), M. depressa was sampled at Jougne in a cold mountain cirque with a north-east exposure at the foot of Mont d'Or, the highest point of the Doubs département. The area is characterised by the presence of cold chimney scree sheltering many plant species with an affinity for subalpine habitats (FERNEZ et al. 2007). Empty shells were collected under rocks at five points (lo- 
calities J01 to J05) spread among two large limestone screes, covered by beech-fir forest, between 1,155 and 1,300 $\mathrm{m}$ in altitude (Fig. 5). A total of 39 gastropod species were observed (Appendix 1). The list of accompanying species is strongly biased towards the presence of taxa with montane affinities, such as Cochlodina fimbriata (Rossmässler, 1835), Discus ruderatus (W. Hartmann, 1821), Ena montana (Draparnaud, 1801), Eucobresia diaphana (Draparnaud, 1805), Isognomostoma isognomostomos (Schröter, 1784), Macularia sylvatica (Schröter, 1784) or Trochulus villosus (Draparnaud, 1805).

In the Vosges Mts. (Fig. 2), empty shells and/or live animals were found at three distinct locations (localities V01 to V03) in beech or beech-fir forests on screes at altitudes between 560 and 675 metres. Two sites (V02 and V03) are situated in deep valleys located in the southern Vosges in the Territoire de Belfort département (Figs 3-4) and one (V01) is located at a valley entrance in central Vosges, in the Haut-Rhin département (Fig. 6).

The Riervescemont locality (V03) is a very open landscape, consisting of a scree dotted with a few fir and birch trees (Fig. 4). The Lamadeleine-Val-desAnges locality (V02) is a small and relatively flat scree with dense leaf-litter between boulders within a beech-fir forest (Fig. 3). A total of 11 gastropod species were observed in this habitat (Appendix 1).

In Mittlach (V01), M. depressa was collected in a large and deep granitic scree on a steep slope with sparse beech trees and a dense, continuous, understory mainly composed of mosses and ferns (Figs 6, 15). A total of 13 gastropod species were observed in this habitat (Appendix 1). Only A. arbustorum, I. isognomostomos and $O$. cellarius were observed syntopical-

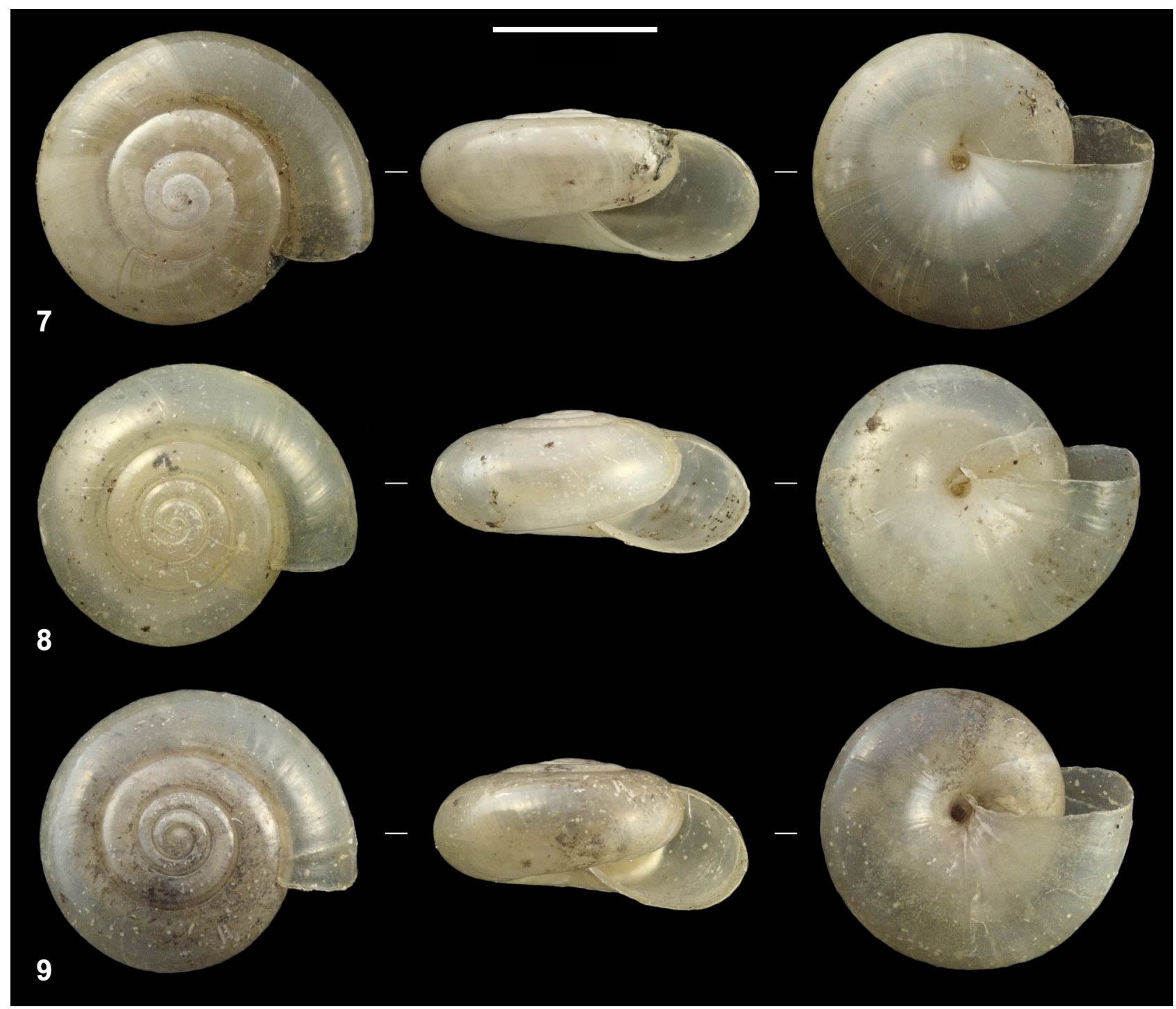

Figs 7-9. Shells of Mediterranea depressa (Sterki, 1880): 7 - specimen from Lamadeleine-Val-des-Anges (locality V02), southern Vosges (shell diameter $=8.45 \mathrm{~mm}$ ); 8 - specimen from Jougne (locality J03), Jura (shell diameter $=8.25 \mathrm{~mm}$ ); 9 - specimen from Jougne (locality J05), Jura (shell diameter $=8.28 \mathrm{~mm}$ ). Scale bar $4 \mathrm{~mm}$ 

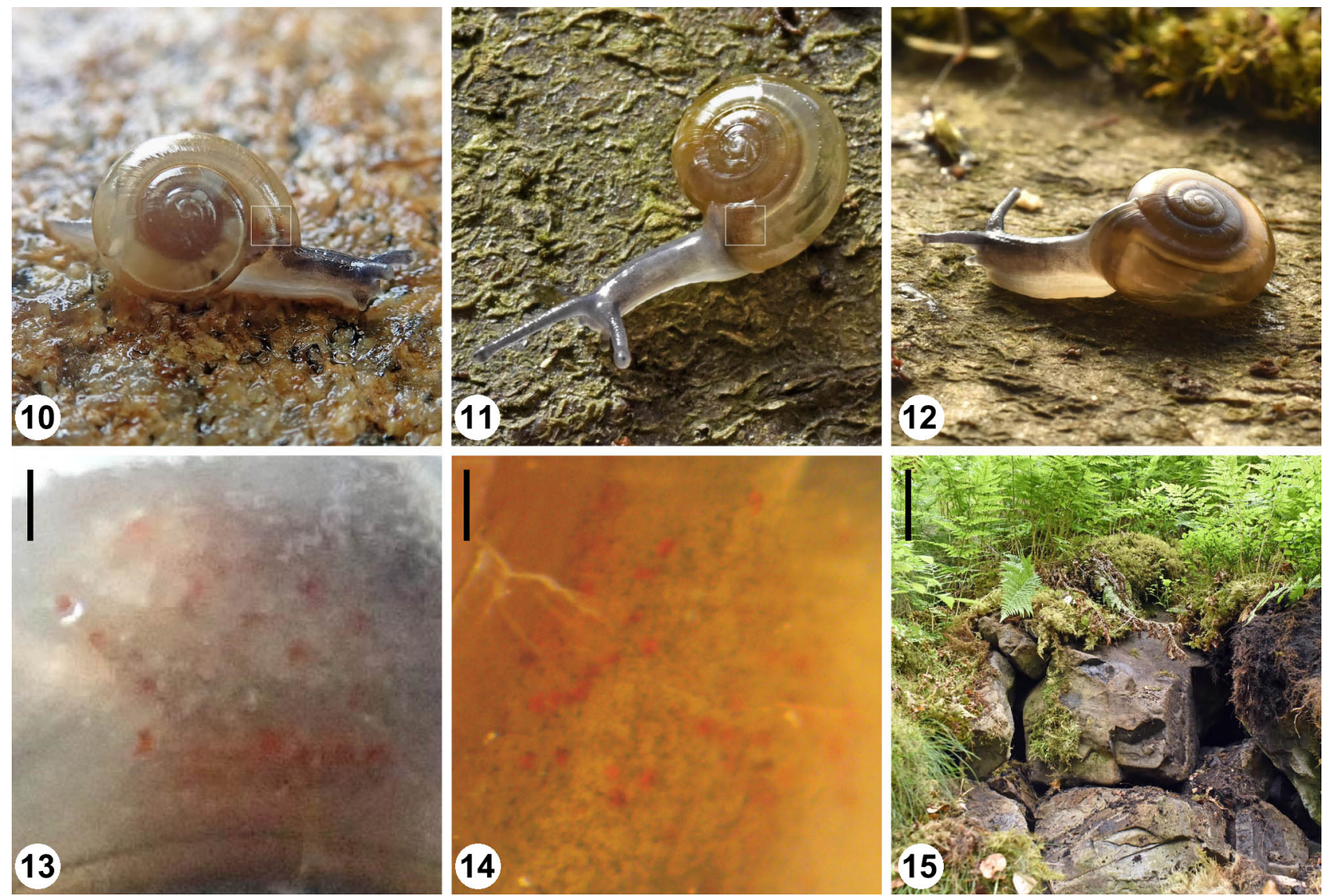

Figs 10-15. Live specimens and micro-habitat of Mediterranea depressa (Sterki, 1880) in the Vosges Mountains: 10 - juvenile specimen from Riervescemont (locality V03, shell diameter $=7.9 \mathrm{~mm}$ ); 11 - juvenile specimen from Mittlach (locality V01, shell diameter $=5.80 \mathrm{~mm}$ ); 12 - adult specimen from Mittlach (shell diameter $=8.11 \mathrm{~mm}$ ); 13 - red dots on the mantle present in the specimen illustrated in Fig. 10; 14 - red dots on the mantle present in the specimen illustrated in Fig. 11; 15 - interstitial rock system where live specimens were sampled at Mittlach. Scale bars $0.2 \mathrm{~mm}$ $(13-14)$ and $25 \mathrm{~cm}(15)$

ly with $M$. depressa between the boulders, deep under the vegetation cover.

At all sites in the two massifs, empty shells and live individuals of $M$. depressa were exclusively collected under boulders, adhering to them or in the underlying litter.

Shell morphology and soft body tissue coloration: Of the total of 21 shells (Figs 7-9), 11 adult (NW $\geq 4$ ) and unbroken shells were measured. Adult shells are flat, usually white or pale yellowish to brownish yellow, thin and translucent with about 4.0-4.5 weakly convex whorls. The shell sculpture of axial striae is not very pronounced except near the suture, which gives the shell a shiny appearance. The shells reach a diameter of up to $8.7 \mathrm{~mm}$ (SW: mean $=7.87 \pm$ $0.75 \mathrm{~mm}$, range $6.29-8.72 \mathrm{~mm}$ ) and $4 \mathrm{~mm}$ in height (SH: mean $=3.72 \pm 0.29 \mathrm{~mm}$, range $3.08-4.04 \mathrm{~mm}$ ). The aperture is up to $4.68 \mathrm{~mm}$ in width (AW: mean $=4.15 \pm 0.41 \mathrm{~mm}$, range $3.33-4.68 \mathrm{~mm}$ ) and up to $3.42 \mathrm{~mm}$ in height $(\mathrm{AH}$ : mean $=3.13 \pm 0.22 \mathrm{~mm}$, range $2.67-3.42 \mathrm{~mm}$ ). The umbilicus is deep, narrow, with a diameter (UW: mean $=0.51 \pm 0.09 \mathrm{~mm}$, range $0.38-0.64 \mathrm{~mm}$ ) not exceeding one sixth of the aperture width (AW) or about one thirteenth of the shell width (SW).

Two live adults and five juveniles were examined (Figs 10-14). The body of the animal is light blue-grey, slightly darker dorsally and on the head. In juveniles, red mantle glands are visible through the translucent upper side of the body whorl (Figs 13-14). A few red spots may remain in young adults, but most granulations become milky white in adults.

All these characters correspond perfectly with the previous descriptions of the species (GERMAIN 1931, KeRNEY et al. 1999, WeLter-SCHULTES 2012, HORSÁK et al. 2013).

Reproductive system: Two adult individuals were examined. The penis $(\mathrm{P})$ has a cylindrical base expanding apically (Fig. 16) and a short, thick epiphallus (E), which extends over about $1 / 3$ of the penis length. The epiphallus is attached laterally along the penis by connective tissue. The penial retractor (PR) and epiphallus are inserted apically on the penis. The distal part of the penis is covered by a sheath (PS) 


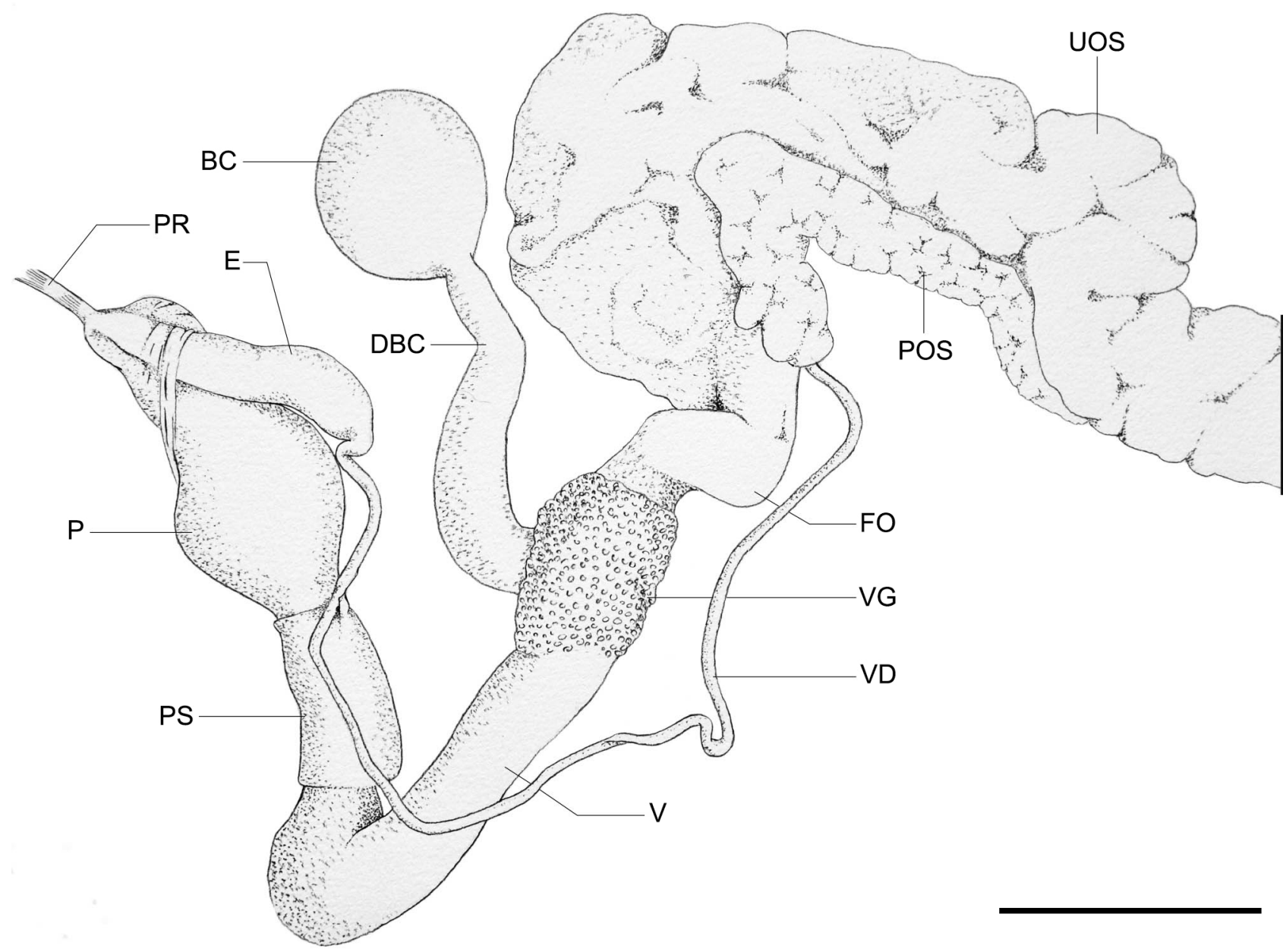

Fig. 16. Distal part of the reproductive system of a specimen of Mediterranea depressa (Sterki, 1880) from the Vosges Mountains at Mittlach (locality V01). For lettering see Abbreviations. Scale bar $1 \mathrm{~mm}$

from which adhesions connect to the vas deferens (VD). The internal sculpture of the penis consists of pleats and rows of papillae, some or all with apical thorns (not illustrated here, observed by us on one of the two specimens). However, the apical spines may be missing in sub-adult specimens (CIANFANELLI et al. 2005) and this is probably the case of the second specimen. In addition, the inner wall of the epiphallus shows series of transverse pilasters on one side and a few slender longitudinal pilasters on the other. The perivaginal gland (VG) consists of dense, yel- lowish glandular tissue which covers the distal part of the free oviduct (FO) but also part of the vagina $(\mathrm{V})$ at the junction with the insertion of the bursa copulatrix duct (DBC). The bursa copulatrix (BC) is round and, in anatomical position, embedded within the folds of the uterine portion of the spermoviduct (UOS).

All these anatomical characters also match the description of the species given in the literature (RIEDEL 1957: figs 29-31, 1969: figs 12 and 16-19, NEGREA 1975, CIANFANELLI et al. 2005: figs 6 and 9).

\section{DISCUSSION}

We report here the first record of $M$. depressa in north-eastern France, in the Vosges and Jura massifs. The live specimens, shells and reproductive anatomy of the specimens we sampled and examined match the diagnostic characters provided for the species (RIEDEL 1957, 1969, NEGREA 1975, KeRneY et al. 1999, CiANFANELLI et al. 2005). The species differs from Oxychilus cellarius and O. navarricus in having a much narrower umbilicus and from Morlina glabra in having a much lower spire and a smaller adult size. Besides, the shells of $M$. depressa have a translucent white colouration unlike the dark brown shells of these other species, except for $O$. cellarius which is very similar both in shell and body colour. However, whereas atypical specimens of M. glabra may have shell morphology or colour resembling those of $M$. 
depressa (JULIEN RYELANDT, unpublished data), the characters of the reproductive system can be used to differentiate the two species. $M$. depressa presents a penis distinctly bulging in its apical half, which is not the case in M. glabra. In addition, M. glabra has a large fold on the inner wall of the penis, absent in $M$. depressa. Furthermore, juvenile $M$. depressa can be distinguished by the presence of red spots on the upper and distal part of the mantle. This pigmentation is clearly visible through the shell at the end of the body whorl. To our knowledge, this character was only reported by CIANFANELLI et al. (2005) and WELTER-SCHULTES (2012) and therefore we cannot state whether it can be used as a reliable diagnostic feature.

As far as we know, the localities described here in north-eastern France represent the westernmost occurrences of the species (WELTER-SCHULTES 2012, NEIBER 2017). Although never recorded before, the presence of the species in this area is not surprising. Indeed, the natural habitats of the Vosges are relatively close to those found further east in the Black Forest mountains (Germany) where the species was already documented (www.bw.mollusca.de, accessed July 15th, 2021). Moreover, its presence on the other side of the border in the Swiss Jura - although very rare and localised (www.cscf.ch, accessed July 15th, 2021) - made its presence very likely on the French side.

Current knowledge of molluscs in north-eastern France is based on nearly 60,000 records for 272 continental species including 144 terrestrial gastropods (BICHAIN et al. 2021). By comparison, Switzerland and Baden-Württemberg, with areas two to three times smaller than that of these two regions of north-eastern France, are documented by approximately 280,000 records (for 293 molluscs species, of which 211 are terrestrial, www.cscf.ch) and 85,000 records (for 266 species, of which 166 are terrestrial, ARBEITSGRUPPE MOLLUSKEN BW 2008), respectively (RÜETSCHI et al. 2012, FRANÇOIS CLAUDE 2021, personal communication). This represents a sampling effort four times less intensive in this part of France than in the neighbouring areas of Switzerland and Germany and may explain why the presence of $M$. depressa has remained unreported until now in north-eastern France.

We only found $M$. depressa in various types of scree and/or boulder fields. These habitats are not strictly classified (MAMMOLA et al. 2016) as Mesovoid Shallow Substratum (MSS, CULVER \& PIPAN 2013; originally called Milieu Souterrain Superficiel by JUBERTHIE et al. 1980), but share common characteristics with that category. In general, MSSs are aphotic near-surface habitats ( $<10$ metres) and consist of air-filled void systems within rocky fragments, usually regarded as suitable for the survival of troglobiont organisms (MAMmOLA et al. 2016). The MSSs are regarded as intermediate zones between the superficial soil horizons (edaphic area) and the deep subterranean environments, which are represented by caves and deep fissure systems. Some authors disagree with this view and consider MSSs as full-fledged subterranean habitats and not as transitional zones (GIACHINO \& VAILATI 2010). In addition to the absence of light, MSSs are characterised by attenuated daily and annual temperature fluctuations, generally higher humidity than at the surface and overall higher allochthonous energy inputs from the surface than in deep subterranean environments (CULVER \& PIPAN 2019). The fauna is composed of troglobionts, i.e. organisms that are strictly subterranean, but also of other organisms that can spend their entire life cycle underground. These may actively or accidentally colonise the MSS. Knowledge of molluscs in these habitats remains very patchy because sampling is particularly difficult and provides only a very partial view of the ecology of these species (RENDOš et al. 2014).

Moreover, gastropod species diversity and population densities are low in this type of habitat, especially on low $\mathrm{pH}$ granitic substratum, where the shells do not remain intact for long. All these elements may explain why $M$. depressa had not been found until now in the Vosges Mts.

In all of our samples in which we detected $M$. depressa, several additional species also considered to have affinities with subterranean environments are present, such as $O$. cellarius, O. alliarius or Vitrea species.

In north-eastern France, but also in northern Italy (CIANFANELLI et al. 2005), it is interesting to note that $M$. depressa seems to be present only in this type of hypogean habitat, whereas in the centre of its range the species colonises many other epigeous environments (KERNEY et al. 1999, WELTER-SCHULTES 2012, NEIBER 2017).

With $M$. depressa, about 30 other species of terrestrial and freshwater gastropods (hydrobioids and slugs excluded from this count) reach their westernmost limit in north-eastern France (Appendix 2 ), i.e. nearly $7 \%$ of the 445 indigenous gastropod species (hydrobioids and slugs also excluded from this count) listed from the French metropolitan territory, including Corsica. Of these, 14 are restricted to north-eastern France (BICHAIN et al. 2019, 2021; species marked with an asterisk in Appendix 2). This geographical part of France, which includes the Vosges and Jura massifs, belongs to a transition zone between the Atlantic and Continental climates. It therefore represents a physical and biogeographical boundary marking the western limit of the ranges of some central and eastern European snail species. 
Additionally, the Vosges and Jura are low-altitude mountains with cold, sub-boreo-alpine climate and several northern and alpine species are present, such as Causa holosericea (S. Studer, 1820), Columella columella (G. von Martens, 1830), Discus ruderatus (W. Hartmann, 1821), Macularia sylvatica (Draparnaud, 1801), Nesovitrea petronella (L. Pfeiffer, 1853), Pupilla alpicola (Charpentier, 1837), P. sterrii (Voith, 1840), Vertigo genesii (Gredler, 1856) or V. geyeri Lindholm, 1925. In the Jura, the presence of these species is best explained by the specific north-east to south-west orientation of the mountain range, which generates strong annual temperature variations (with extremes ranging from $-40{ }^{\circ} \mathrm{C}$ to $35^{\circ} \mathrm{C}$ in the same location) with a warm southern flow in summer and a cold northern flow in winter (TRAUTSOLT 1969). In addition, erosion and successive glaciations have generated an important karstic network and favoured the emergence of unique habitats and refuges sheltering a suite of relict boreo-alpine species (CASTELLARINI et al. 2007, SCHMITT et al. 2010, BUONCRISTIANI \& CAMPY 2011, HAMPE \& JUMP 2011), be it among plants or insects. All these factors also allow an alpine malacofauna to maintain itself within these latitudes at a relatively low altitude. The situation is similar in the Vosges, with annual temperatures variations close to those of Reykjavik in Iceland (SELL et al. 1998). However, apart from the limestone foothills located at the eastern part of the massif, the vast majority of the Vosges consists of siliceous rocks such as granite or sandstone, that is, rocks extremely unfavourable for snails. Only about fifty species of terrestrial gastropods have been recorded in the Vosges massif (GEISSERT 1963 and associated litera- ture), which is poor compared to the calcareous areas of the Jura, for which about 120 species have been recorded (BICHAIN et al. 2021) and where a single site can have up to forty species.

The discovery of $M$. depressa confirms the unique character of these two areas as parts of a biogeographical transition zone but also shows the need to increase sampling efforts in difficult-to-access and therefore poorly-known environments. An extensive field campaign seems necessary to better understand the real distribution of the species in these two regions and the diversity of these habitats, but also to assess potential threats facing populations.

\section{ACKNOWLEDGEMENTS}

We thank KeVIN UMBRECHT (Society and Museum of Natural History and Ethnography, Colmar - France) for his help in designing Figure 1 and FrançOIS Claude (Swiss Centre for Wildlife Cartography - CSCF) for the various information provided during the writing of this article. We also warmly thank MiCHAL HORSÁK, PHILIPPE BOUCHET and EMMANUEL FARA for their helpful comments and corrections that improved the manuscript. We also thank the two reviewers for their constructive comments. Finally, we would like to thank the members of the scientific community who, by all contemporary means, provide free and open access to their publications. Special thanks go to ALEXANDRA ELBAKYAN (Sci-Hub) and the managers of the ResearchGate website for their significant contribution to the democratisation of research products. Special thanks go to LOUISE BICHAIN for her assistance in the field.

\section{REFERENCES}

ARBEITSGRUPPE MOLLUSKEN BW 2008. Rote Liste und Artenverzeichnis der Schnecken und Muscheln Baden-Württembergs. Vol. 12. Verlagspublikation Umweltverwaltung Baden-Württemberg, Karlsruhe. https://pudi.lubw.de/detailseite/-/publication/39211

BAnK R. A., Neubert E. 2017. Checklist of the land and freshwater Gastropoda of Europe. Last update: July 16th, 2017. 170 pp. Available at http://www.marinespecies.org/aphia.php? $\mathrm{p}=$ sourcedetails\&id $=279050$.

BiCHAIN J.-M., CUCHERAT X., BRULÉ H., DURR T., GUHRING J., HOMMAY G., RYELANDT J., UMBRECHT K. 2019. Liste de référence fonctionnelle et annotée des mollusques continentaux (Mollusca: Gastropoda \& Bivalvia) du Grand-Est (France). Naturae 11: 285-333. https://doi.org/10.5852/naturae2019a11

Bichain J.-M., UMbReCHT K., RYElandT J., CUCHERAT X. 2021. Priorités régionales de conservation pour les mollusques continentaux: un défi pour les taxons mal documentés. Naturae 14: 183-211. https://doi.org/10.5852/naturae2021a14

BUONCRISTIANI J.-F., CAMPY M. 2011. Quaternary glaciations in the French Alps and Jura. In: EHLERS J., GIBBARD P. L., Hughes P. D. (eds). Quaternary glaciations - extent and chronology: a closer look. Developments in Quaternary Science 15: 117-126. https://doi.org/10.1016/B978-0-444-53447-7.00010-6

Castellarini F., Malard F., Dole-Olivier M. J., GiberT J. 2007. Modelling the distribution of stygobionts in the Jura Mountains (Eastern France). Implications for the protection of ground waters. Diversity and Distributions 13: 213-224.

https://doi.org/10.1111/j.1472-4642.2006.00317.x

ChARPENTIER J. DE 1837. Catalogue des mollusques terrestres et fluviatiles de la Suisse. Nouveaux Mémoires de la Société Helvétique des Sciences Naturelles 1(2): 1-28, pls 1-2. Neuchâtel.

https://www.biodiversitylibrary.org/page/13860030

Cianfanelli S., Manganelli G., Giusti F. 2005. New data on the systematics and distribution of the oxychiline zonitid Mediterranea depressa (Sterki, 1880) in 
Italy (Gastropoda: Pulmonata: Zonitidae). Journal of Conchology 38: 639-648.

Culver D. C., PIPAN T. 2013. Subterranean ecosystems. Encyclopedia of Biodiversity, Elsevier, pp. 49-62. https://doi.org/10.1016/B978-0-12-384719-5.00224-0

DAYRAT B. 2005. Towards integrative taxonomy. Biological Journal of the Linnean Society 85: 407-415. https://doi.org/10.1111/j.1095-8312.2005.00503.x

DRAPARNAUD J.-P.-R. 1801. Tableau des mollusques terrestres et fluviatiles de la France. Bossange, Masson \& Besson, Montpellier / Renaud, Paris. https://doi.org/10.5962/bhl.title.40947

DRAPARNAUD J.-P.-R. 1805. Histoire naturelle des mollusques terrestres et fluviatiles de la France. Levrault \& Schoell, Paris. https://www.biodiversitylibrary.org/page/52682088

Eller J. P. von, Blanalt J. G., Hameurt J., Hollinger J., HoepfFner C. 1970a. Carte géologique du socle vosgien, partie septentrionale, et notice explicative. Bulletin du Service de la carte géologique d'Alsace et de Lorraine 23: 5-28. https://doi.org/10.3406/sgeol.1970.1365

Eller J. P. VON, FlüCK P., HAMEURT J. 1970b. Carte géologique des Vosges moyennes, partie centrale et partie orientale et notice explicative. Bulletin du Service de la carte géologique d'Alsace et de Lorraine 23: 29-50. https://doi.org/10.3406/sgeol.1970.1366

FALKNER G., BANK R. A., PROSCHWITZ T. vON 2001. Checklist of the non-marine molluscan species-group taxa of the states of Northern, Atlantic and Central Europe (CLECOM I). Heldia 4: 1-76.

FALKNER G., RIPKEN T. E. J., FALKNER M. 2002. Mollusques continentaux de la France: liste de référence annotée et bibliographie. Patrimoines naturels 52, Muséum national d'Histoire naturelle, Paris.

FAVRE J. 1927. Les mollusques post-glaciaires et actuels du bassin de Genève. Mémoires de la Société de physique et d'histoire naturelle de Genève 40: 171-434.

FEHÉr Z., ERŐSS Z. P. 2009. Checklist of the Albianian mollusc fauna. Schriften zur Malakozoologie 25: 22-38.

FERnez T., Guinchard P., GuinCHARd M. 2007. Typologie des habitats du site Natura 2000 "Massif du Mont d'Or, du Noirmont et du Risol " et test cartographique. Conservatoire botanique de Franche-Comté, DIREN Franche-Comté, Conseil Général du Doubs, Union Européenne, Besançon.

FITZINGER L. J. 1833. Systematisches Verzeichniß der im Erzherzogthume Oesterreich vorkommenden Weichthiere, als Prodrom einer Fauna derselben. Beiträge zur Landeskunde Oesterreichs's unter der Enns 3: 88-122. Wien.

https://biodiversitylibrary.org/page/10601570

FlÜCK P., PIQUÉ A., SCHNEIDER J.-L., WhITECHURCH H. 1991. Le socle vosgien. Sciences Géologique, Bulletin 44: 207-235. https://doi.org/10.3406/sgeol.1991.1867

GEISSERT F. 1963. Les mollusques. In: Le Hohneck, aspects physiques, biologiques et humains. Association Philomathique d'Alsace et de Lorraine, pp. 323-330.
GERMAIN L. 1931. Mollusques terrestres et fluviatiles. Faune de France Vol. 21. Paul Lechevalier, Paris. https://archive.org/details/FauneDeFrance21-22

GIACHINO P. M., VAILATI D. 2010. The subterranean environment: hypogean life, concepts and collecting techniques $=$ Lambiente sotterraneo: vita ipogea, concetti e tecniche di raccolta. WBA handbooks 3, Verona.

GredLER V. M. 1856. Tirols Land- und SüßwasserConchylien I. Die Landconchylien. Verhandlungen der Kaiserlich-königlichen Zoologisch-botanischen Gesellschaft in Wien 6: 25-162.

https://www.biodiversitylibrary.org/page/16414458

HAMPE A., JUMP A. S. 2011. Climate relicts: past, present, future. Annual Review of Ecology, Evolution, and Systematics 42: 313-333.

https://doi.org/10.1146/annurev-ecolsys-102710-145015

HARTMANN J. D. W. 1821. System der Erd- und Flußschnecken der Schweiz. Mit vergleichender Aufzählung aller auch in den benachbarten Ländern, Deutschland, Frankreich und Italien sich vorfindenden Arten. In: STEINMUller J. R. (ed.). Neue Alpina. Eine Schrift der Schweizerischen Naturgeschichte, Alpen- und Landwirthschaft gewiedmet, Erster Band, Winterthur, pp. 194-268, pl. 1-2.

https://biodiversitylibrary.org/page/41756566\#page/206/ mode/lup

HorsÁK M., JuŘíčKovÁ L., PICKA J. 2013. Molluscs of the Czech and Slovak Republics. Nakladatelstvi Kabourek, Zlin.

HuANG C.-W., LEE Y.-C., LIN S.-M., WU W.-L. 2014. Taxonomic revision of Aegista subchinensis (Möllendorff, 1884) (Stylommatophora, Bradybaenidae) and a description of a new species of Aegista from eastern Taiwan based on multilocus phylogeny and comparative morphology. ZooKeys 445: 31-55. https://doi.org/10.3897/zookeys.445.7778

HuDEC V. 1961. Zur Diskussion über die Schnecke Oxychilus (Riedelius) inopinatus (Uličný, 1887). Sbornik Národniho Musea v Praze (B) 16: 97-128.

Juberthie C., Delay B., Bouillon M. 1980. Sur l'existence d'un milieu souterrain superficiel en zone non calcaire. Comptes Rendus de l'Académie des Sciences 290: 49-52.

JUŘIČKOVÁ L., KUČERA T. 2005. Ruins of medieval castles as refuges for endangered species of molluscs. Journal of Molluscan Studies 71: 233-246.

https://doi.org/10.1093/mollus/eyi031

Kerney M. P., Cameron R. A. D., Bertrand A. 1999. Guide des escargots et limaces d'Europe: identification et biologie de plus de 300 espèces. Delachaux et Niestlé, Lausanne.

Kocot-ZALEWSKA J., DOMAGAŁA P. 2020. Terrestrial invertebrate fauna of Polish caves - a summary of 100 years of research. Subterranean Biology 33: 45-69. https://doi.org/10.3897/subtbiol.33.48805

LINDHOLM W. A. 1925. Studien an palaearktischen VertigoArten. Archiv für Molluskenkunde 57: 241-251.

Mammola S., Giachino P. M., PiAno E., JONeS A., BARBERIS M., BADINO G., ISAIA M. 2016. Ecology and sampling techniques of an understudied subterranean 
habitat: the Milieu Souterrain Superficiel (MSS). The Science of Nature 103: 88.

https://doi.org/10.1007/s00114-016-1413-9

MARTENS G. VON 1830. Natur- und Vaterlandskunde. Ueber Würtembergs Fauna. Correspondenzblatt des Würtembergischen Landwirthschaftlichen Vereins 17(3): 123-186.

Negrea A. 1975. Contribution à l'étude des Zonitidae (Gastropoda) cavernicoles et endogés de Roumanie. International Journal of Speleology 6: 303-324. https://doi.org/10.5038/1827-806X.6.4.2

NeIBER M. T. 2017. Mediterranea depressa. The IUCN Red List of Threatened Species 2017: e.T171438A1326174. https://doi.org/10.2305/IUCN.UK.2017-3.RLTS. T171438A1326174.en

PFEIFFER L. 1853. Monographia heliceorum viventium. Sistens descriptiones systematicas et criticas omnium huius familiae generum et specierum hodie cognitarum. Vol. 3. Brockhaus, Lipsiae.

Rendoš M., ČejKA T., ŠTeFFeK J., Mock A. 2014. Land snails from subterranean traps exposed in a forested scree slope (Western Carpathians, Slovakia). Folia Malacologica 22: 255-261. https://doi.org/10.12657/folmal.022.022

RIEDEL A. 1957. Revision der Zonitiden Polens (Gastropoda). Annales Zoologici 16: 361-465.

RIEDEL A. 1969. Die Untergattungen Morlina A. J. Wagner und Riedelius Hudec der Gattung Oxychilus Fitzenger (Gastropoda, Zonitidae). Annales Zoologici 27: 91-131.

Riedel A. 1980. Genera Zonitidarum. Diagnosen supraspezifischer Taxa der Familie Zonitidae (Gastropoda, Stylommatophora). Dr Backhuys, Rotterdam.

RIEDEL A. 1998. Genera Zonitidarum - Addenda et corrigenda (Gastropoda, Stylommatophora). Polska Akademia Nauk, Muzeum i Instytut Zoologii, Warszawa.

ROSSMÄSSLER E. A. 1835. Iconographie der Land\& Süßwasser- Mollusken, mit vorzüglicher Berücksichtigung der europäischen noch nicht abgebildeten Arten. (1) 1 (2): $6+1-26$, pl. 6-10 [ $\geq$ Aug. 1835] \& 1 (3): $4+1-33$, pl. 11-15 [ $\geq$ Mar. 1836]. Arnoldische Buchhandlung, Dresden und Leipzig.

RÜETSCHI J., STUCKI P., MÜLler P., VICENTINI H., ClAUdE F. 2012. Liste rouge Mollusques (Gastéropodes et bivalves). Espèces menacées en Suisse, état 2010. Centre suisse de cartographie de la faune CSCF, Berne.
SCHILEYKO A. A. 2003. Treatise on recent terrestrial pulmonate molluscs. Ruthenica supplement 2 (part 10): 1309-1466.

SCHMitT T., Muster C., SCHÖNSWETTER P. 2010. Are disjunct Alpine and Arctic-Alpine animal and plant species in the Western Palearctic really "Relics of a Cold Past”? In: HABEL J. C., ASSMANN T. (eds). Relict species. Springer Verlag, Berlin, Heidelberg, pp. 239-252. https://doi.org/10.1007/978-3-540-92160-8_13

SCHRÖTER J. S. 1784. Einleitung in die Conchylienkenntniss nach Linné. Zweyter Band, Nebst vier Kupfertafeln. Gebauer, Halle. https://doi.org/10.5962/bhl.title.118381

Sell Y., BerChtold J. P., CAllot H., Hoff M., Gall J. C., WALTER J. M. 1998. L'Alsace et les Vosges: géologie, milieux naturels, flore et faune. Delachaux et Niestlé, Lausanne.

STERKI V. 1880. Hyalina depressa n. sp. Nachrichtsblatt der deutschen malakozoologischen Gesellschaft 12(10): 104-105.

STUDER S. 1820. Kurzes Verzeichnis der bis jetzt in unserm Vaterlande entdeckten Conchylien. Naturwissenschaftlicher Anzeiger der Allgemeinen Schweizerischen Gesellschaft für die Gesammten Naturwissenschaften 3(11): 83-90; (12): 91-94.

SysOeV A., SCHILEYKO A. 2009. Land snails and slugs of Russia and adjacent countries. Pensoft Series Faunistica; 87. Pensoft Publishers, Sofia.

TRAuTSOlT I. 1969. Recherches sur les climats du Jura français. Annales de Géographie 78(428): 405-434. https://doi.org/10.3406/geo.1969.15892

VOITH I. VON 1840. Forster F.: Animalia mollusca. Mit Anmerkungen von I. v. Voith. In: FürNROHR A. E. (ed.). Naturhistorische Topographie von Regensburg. In Verbindung mit Forster, Herrich-Schäffer, Koch, v. Schmöger und v. Voith. Dritter Band, die Fauna von Regensburg enthaltend. Regensburg, pp. 459-478.

WELTER-SCHULTES F. W. 2012. European non-marine molluscs, a guide for species identification. Planet Poster Editions, Göttingen.

Received: August 11th, 2021

Revised: September 29th, 2021

Accepted: October 26th, 2021

Published on-line: November 29th, 2021 


\section{APPENDIX 1}

Species recorded in scree and boulder fields in the Vosges and Jura Mts. (see Material and Methods for details of each locality). Anatomical characters were used to identify Aegopinella and Oxychilus spp.

\begin{tabular}{|c|c|c|c|c|c|c|c|c|}
\hline & V01 & V02 & V03 & J01 & J02 & J03 & J04 & J05 \\
\hline Abida secale (Draparnaud, 1801) & & & & & & $x$ & $x$ & $x$ \\
\hline Acanthinula aculeata (O. F. Müller, 1774) & $x$ & & & & & & & \\
\hline Aegopinella nitens (Michaud, 1831) & & & & $x$ & & $x$ & $x$ & $x$ \\
\hline Aegopinella nitidula (Draparnaud, 1805) & & $x$ & & & & & & \\
\hline Aegopinella pura (Alder, 1830) & $\times$ & $x$ & & & & $\times$ & $x$ & $\times$ \\
\hline Arianta arbustorum (Linnaeus, 1758) & $\times$ & $x$ & & & $x$ & $\times$ & $x$ & \\
\hline Cepaea hortensis (O. F. Müller, 1774) & $\times$ & & & & $\times$ & & & \\
\hline Cepaea nemoralis (Linnaeus, 1758) & & $\times$ & & & & & & \\
\hline Chondrina avenacea (Bruguière, 1792) & & & & & & & & $x$ \\
\hline Clausilia bidentata (Strøm, 1765) & $x$ & & & & & & $x$ & \\
\hline Clausilia cruciata (S. Studer, 1820) & & & & $\times$ & & & & \\
\hline Clausilia dubia Draparnaud, 1805 & & & & & & $x$ & & \\
\hline Clausilia rugosa parvula A. Férussac, 1807 & & & & & & $x$ & & $x$ \\
\hline Cochlicopa lubrica (O. F. Müller, 1774) & & & & & & $\times$ & & \\
\hline Cochlodina fimbriata (Rossmässler, 1835) & & & & $x$ & & $x$ & & $\times$ \\
\hline Cochlodina laminata (Montagu, 1803) & & & & & & $x$ & & $\times$ \\
\hline Cochlostoma septemspirale (Razoumowsky, 1789) & & & & $\times$ & $\times$ & $\times$ & & $x$ \\
\hline Discus rotundatus (O. F. Müller, 1774) & $x$ & $x$ & & $\times$ & $x$ & $x$ & & $\times$ \\
\hline Discus ruderatus (W. Hartmann, 1821) & & & & & & $x$ & & $\times$ \\
\hline Edentiella edentula (Draparnaud, 1805) & & $x$ & & $x$ & & & $x$ & \\
\hline Ena montana (Draparnaud, 1801) & $x$ & & & $x$ & $x$ & & & \\
\hline Eucobresia diaphana (Draparnaud, 1805) & & $\times$ & & $\times$ & & $\times$ & $\times$ & \\
\hline Euconulus fulvus (O. F. Müller, 1774) & & & & $x$ & $x$ & $x$ & & $x$ \\
\hline Helicigona lapicida (Linnaeus, 1758) & $\times$ & $x$ & $\times$ & & & $\times$ & $x$ & $x$ \\
\hline Helicodonta obvoluta (O. F. Müller, 1774) & $\times$ & $x$ & & $\times$ & $\times$ & $\times$ & $x$ & $x$ \\
\hline Helix pomatia Linnaeus, 1758 & & $x$ & & $x$ & & & & \\
\hline Isognomostoma isognomostomos (Schröter, 1784) & $\times$ & $\times$ & $\times$ & $\times$ & $\times$ & $\times$ & $\times$ & $\times$ \\
\hline Macrogastra plicatula (Draparnaud, 1801) & & & & & $x$ & $\times$ & $x$ & $x$ \\
\hline Macrogastra ventricosa (Draparnaud, 1801) & & & & $\times$ & & $\times$ & & \\
\hline Macularia sylvatica (Draparnaud, 1801) & & & & & $\times$ & $x$ & $x$ & $x$ \\
\hline Mediterranea depressa (Sterki, 1880) & $\times$ & $x$ & $x$ & $\times$ & $x$ & $x$ & $x$ & $x$ \\
\hline Merdigera obscura (O. F. Müller, 1774) & & & & $\times$ & & & & \\
\hline Monachoides incarnatus (O. F. Müller, 1774) & $x$ & $x$ & & $\times$ & & & & \\
\hline Nesovitrea hammonis (Strøm, 1765) & $x$ & & & & & & & $x$ \\
\hline Orcula dolium (Draparnaud, 1801) & & & & & & & & $x$ \\
\hline Oxychilus alliarius (J. S. Miller, 1822) & & $x$ & & & & & & \\
\hline Oxychilus cellarius (O. F. Müller, 1774) & $x$ & $x$ & $x$ & & & $x$ & & $\times$ \\
\hline Oxychilus draparnaudi (H. Beck, 1837) & & & & & & & & $x$ \\
\hline Oxychilus navarricus helveticus (Blum, 1881) & & $x$ & & & $x$ & $x$ & & \\
\hline Phenacolimax major (A. Férussac, 1807) & $x$ & $x$ & & & & & & \\
\hline Trochulus villosus (Draparnaud, 1805) & & & & $\times$ & $x$ & $x$ & $\times$ & $\times$ \\
\hline Vitrea crystallina (O. F. Müller, 1774) & & & & $\times$ & & $\times$ & $x$ & $x$ \\
\hline Vitrea subrimata (Reinhardt, 1871) & $x$ & & & $x$ & & $x$ & $x$ & $x$ \\
\hline Vitrina pellucida (O. F. Müller, 1774) & & $x$ & & $\times$ & $\times$ & & $x$ & \\
\hline
\end{tabular}




\section{APPENDIX 2}

Gastropod species (hydrobioids and slugs excluded) at the western limit of their range in the north-eastern quarter of France after KERNEY \& CAMERON (1999), WELTER-SCHUlTES (2012) and BiCHAIN et al. (2021) (species marked with an asterisk are only found in France in this region, species marked with a double asterisk have disjoint populations in the Pyrenees or in Spain).

Aegopinella minor (Stabile, 1864)**

Aegopinella nitens (Michaud, 1831)

Cochlodina fimbriata (Rossmässler, 1835)

Cochlodina orthostoma (Menke, 1828)*

Columella columella (G. von Martens, 1830)

Clausilia corynodes saxatilis (W. Hartmann, 1843)*

Clausilia cruciata (S. Studer, 1820)*

Daudebardia brevipes (Draparnaud, 1805)*

Daudebardia rufa (Draparnaud, 1805)*

Edentiella edentula (Draparnaud, 1805)

Eucobresia diaphana (Draparnaud, 1805)

Gyraulus rossmaessleri (Auerswald, 1852)*

Helicopsis striata (O. F. Müller, 1774)*

Hessemilimax kotulae (Westerlund, 1883)*

Isognomostoma isognomostomos (Schröter, 1784)
Laciniaria plicata (Draparnaud, 1801)*

Macrogastra attenuata (Rossmässler, 1835)**

Macularia sylvatica (Draparnaud, 1801)

Mediterranea depressa (Sterki, 1880)

Nesovitrea petronella (L. Pfeiffer, 1853)

Orcula dolium (Draparnaud, 1801)

Platyla polita (W. Hartmann, 1840)

Pupilla alpicola (Charpentier, 1837)

Pupilla sterrii (Voith, 1840)

Semilimax semilimax (J. Férussac, 1802)*

Trochulus clandestinus (W. Hartmann, 1821)*

Trochulus montanus (S. Studer, 1820)

Trochulus villosus (Draparnaud, 1805)

Vallonia declivis Sterki, 1893*

Vitrinobrachium breve (A. Férussac, 1821)* 